\title{
Multiple Types of High-Threshold Calcium Channels in Rabbit Sensory Neurons: High-Affinity Block of Neuronal L-Type by Nimodipine
}

\author{
R. T. McCarthy and P. E. TanPiengco \\ Miles Institute for Preclinical Pharmacology, West Haven, Connecticut 06516
}

\begin{abstract}
Whole-cell and cell-attached patch recording have been used to characterize multiple types of voltage-dependent calcium channels in neurons freshly dispersed from rabbit dorsal root ganglia. In whole-cell patch recordings, high-threshold current, strongly resistant to inactivation by depolarized holding potentials (L-type; $V_{1 / 2}=-27.2 \mathrm{mV}$ ), was potently inhibited by nimodipine. Assuming 1:1 binding, the dissociation constant for nimodipine binding to the inactivated state of the L-type calcium channel $\left(K_{t}\right)$ was $5.3 \mathrm{nM}(n=8)$. In contrast, a second type of high-threshold current less resistant to inactivation by depolarized holding potentials ( $\mathrm{N}$-type; $\boldsymbol{V}_{1 / 2}=$ $-56.9 \mathrm{mV}$ ) was not blocked by nimodipine. Nimodipine-resistant $\mathrm{N}$-type calcium current was inhibited by $\omega$-conotoxin $(5 \mu \mathrm{M})$. Cell-attached patch recordings of single calcium channel currents demonstrated the existence of three ditferent unitary conductances; $7.4 \mathrm{pS}, 13.1 \mathrm{pS}$, and $24.1 \mathrm{pS}$. The $24.1 \mathrm{pS}$ high-threshold channel was enhanced by $(-)$ BAY K 8644 and inhibited by nimodipine in a concentrationand voltage-dependent manner. Hyperpolarization reversed this block. These results demonstrate that, as in cardiac and smooth muscle, there is a component of neuronal highthreshold current corresponding to the L-type calcium channel that can be blocked with high affinity by nimodipine.
\end{abstract}

Despite the existence of high-affinity 1,4-dihydropyridine (DHP) binding sites in central and peripheral neurons (Peroutka and Allen, 1983; Janis et al., 1987; Rampe et al., 1987), the ability of DHP calcium channel antagonists to inhibit calcium current in neurons with high affinity has remained controversial (Boll and Lux, 1985; Docherty and Brown, 1986; Swandulla et al., 1991). Typically, micromolar concentrations of DHPs are used to inhibit calcium influx through voltage-dependent calcium channels (e.g., Fox et al., 1987a,b; Regan, 1991; Regan et al., 1991) though recent experiments in neurons suggest that 300 nM DHP is as effective as $3 \mu \mathrm{M}$ DHP (Docherty and Brown, 1986; A. Fox and B. Bean, personal communications). Few studies have fully investigated the affinity of neuronal calcium currents inhibited by low concentrations of DHP. The presence of multiple types of calcium channels in neurons (Tsien et al., 1988; Bean, 1989; Hess, 1990), some of which are DHP insensitive, may have led to the presumption that DHP-sensitive calcium channels of neurons are less sensitive than their coun-

\footnotetext{
Received Aug. 5, 1991; revised Nov. 8, 1991; accepted Jan. 13, 1992.

Correspondence should be addressed to Richard T. McCarthy, Miles Inc., MIPP, 400 Morgan Lane, West Haven, CT 06516.

Copyright (C) 1992 Society for Neuroscience $0270-6474 / 92 / 122225-10 \$ 05.00 / 0$
}

terparts in cardiac (Bean, 1984; Sanguinetti and Kass, 1984) and smooth muscle (Bean et al., 1986).

We have used the patch voltage-clamp technique in the wholecell and cell-attached configurations to study voltage-dependent calcium channels in neurons freshly dispersed from rabbit dorsal root ganglia (DRG). We provide evidence for the presence of two populations of high-threshold calcium channels corresponding to the L- and N-type channels described in other preparations (e.g., chick DRG; Nowycky et al., 1985a). Heterogeneity in the relative density of these two distinct channel types in different cells and patches of membrane has allowed us to study them together and in isolation. We have found that the channel type best categorized as being L-type is blocked with high affinity by the DHP nimodipine. Our results show that although the relative magnitude of L-type channel current to the overall highthreshold current varies from cell to cell, L-type channels are consistently blocked by nimodipine with the same high affinity as L-type channels of cardiac and smooth muscle.

Some of these results have appeared in abstract form (TanPiengco and McCarthy, 1990).

\section{Materials and Methods}

Dispersal procedures. Ether-anesthetized female New Zealand White rabbits (12-24 weeks; $2.5-4.0 \mathrm{~kg}$ ) were killed and thoracic dorsal root ganglia (T7-T12) surgically removed. Ganglia were trimmed of connective tissue, minced with microdissecting scissors, and enzymatically treated with a calcium- and magnesium-free Hank's balanced salt solution [BSS (10 ml); Hazelton Biologics, Inc., Lenexa, KS] containing collagenase $(1 \mathrm{mg} / \mathrm{ml}$; Worthington Biochemical Corp., Freehold, NJ) and dispase $(5 \mathrm{mg} / \mathrm{ml}$; Boehringer Mannheim Biochemicals, Indianapolis, IN) for $20 \mathrm{~min}$ at $37^{\circ} \mathrm{C}$. Dispersed ganglia were centrifuged (10 min at $200 \times g$ ), resuspended in Hank's BSS by triturating with a firepolished Pasteur pipette, and then digested a second time in Hank's BSS $(10 \mathrm{ml})$ containing dispase only $(20 \mathrm{~min})$. The cells were centrifuged a second time, the supernatant was discarded, and the cells were resuspended in Hank's BSS $(5 \mathrm{ml})$ and maintained at $37^{\circ} \mathrm{C}$. Four recordings obtained from neurons isolated from male rabbits indicated that the types of calcium currents and pharmacological sensitivity observed were consistent with those in neurons from female rabbits. While the isolation procedure probably was sufficient to eliminate traces of ether in our recordings, we also demonstrated that calcium currents recorded in the absence and presence of $100 \mu \mathrm{M}$ ether (anhydrous, Baker reagent grade) were not significantly different.

Recording solutions. The freshly dispersed sensory neurons (cell bodies: diameter, $25-50 \mu \mathrm{m}$ ) were plated on an untreated coverslip placed in the recording chamber and allowed to settle for 3-5 min. The cells were then rinsed in a solution containing (in $\mathrm{mm}$ ): $\mathrm{NaCl}, 150 ; \mathrm{KCl}, 4.0$; $\mathrm{CaCl}_{2}, 9.0 ; \mathrm{MgCl}_{2}, 0.5 ;$ dextrose, $5 ;$ HEPES, $10 ; \mathrm{pH}$ 7.5. The composition of the bathing solution varied depending on the experimental protocol (see Table 1). Different bathing solutions did not alter the efficacy of drug treatment. The compositions of the whole-cell pipette solutions are given in Table 2. Substitution of 1,2-bis(2-aminophenoxy)ethane- 
Table 1. Whole-cell bath solutions (mM)

\begin{tabular}{lccccc} 
& \multicolumn{1}{l}{ Solution } & \multicolumn{5}{l}{} \\
\cline { 2 - 6 } & $\mathrm{A}$ & $\mathrm{B}$ & $\mathrm{C}$ & $\mathrm{D}$ & $\mathrm{E}$ \\
\hline $\mathrm{BaCl}_{2}$ & 1 & 5 & - & 20 & - \\
$\mathrm{CaCl}_{2}$ & - & - & 5 & - & 20 \\
$\mathrm{TEA}-\mathrm{Cl}^{a}$ & 162 & 156 & 156 & 117 & 117 \\
$\mathrm{MgCl}_{2}$ & 0.5 & 0.5 & 0.5 & 0.5 & 0.5 \\
$\mathrm{HEPES}$ & 10 & 10 & 10 & 10 & 10 \\
Dextrose & 5 & 5 & 5 & 5 & 5 \\
Sucrose & - & - & - & 32 & 32 \\
TTX & $200 \mathrm{nM}$ & $200 \mathrm{nM}$ & $200 \mathrm{nM}$ & $200 \mathrm{nM}$ & $200 \mathrm{nM}$
\end{tabular}

${ }^{a}$ TEA, Tetraethylammonium.

$N, N, N^{\prime}, N^{\prime}$-tetra acetic acid (BAPTA) for EGTA in the pipette solution (Table 2) did not consistently alter the kinetics of calcium channel currents and channels retained the ability to inactivate (Jones and Marks, 1989). Wholc-cell calcium channcl currents clicited under these conditions were completely inhibited by $100 \mu \mathrm{M}$ cadmium. $\omega$-Conotoxin GVIA ( $\omega$-CTX; Peninsula Labs, Belmont, CA) was stored frozen $\left(-14^{\circ} \mathrm{C}\right)$ as a $500 \mu \mathrm{M}$ stock in $\mathrm{H}_{2} \mathrm{O}$.

In cell-attached patch recordings, the pipette solution contained 110 $\mathrm{mm} \mathrm{BaCl}, 10 \mathrm{~mm}$ HEPES, and $200 \mathrm{~nm}$ TTX $\left(\mathrm{pH} 7.4\right.$ with $\mathrm{Ba}(\mathrm{OH})_{2} \cong$ $5 \mathrm{mM}$ ), and a bath solution of (in $\mathrm{mM}$ ) $140 \mathrm{~K}^{+}$-aspartate, $10 \mathrm{~K}$-EGTA, $1 \mathrm{MgCl}_{2}$, and $10 \mathrm{HEPES}(\mathrm{pH} 7.4$ with $\mathrm{KOH}$ ) was used to zero the membrane potential. In two experiments, calcium channel activity was observed in excised patches and the unitary current amplitude after excision was unchanged compared to that in the cell-attached configuration. These observations indicate that the membrane potential of the cell was indeed at, or very close to, $0 \mathrm{mV}$.

Patch voltage-clamp experiments. Freshly dispersed cells were voltage clamped at room temperature $\left(21.0-23.3^{\circ} \mathrm{C}\right.$ ) using a List EPC-7 (Medical Systems, Greenvale, NY) in either the whole-cell or cell-attached patch configuration. Patch electrodes were made from Corning glass ( $\# 7052$; Rae and Levis, 1984) and had resistances between 0.6 and $2.6 \mathrm{M} \Omega$. Patch pipettes were insulated to within $100 \mu \mathrm{m}$ of the tip with Sylgard 184 (Dow Corning) and fire polished with a glass-coated, heated platinum wire.

Voltage pulse generation, data acquisition, and analysis were performed with an LSI 11/23 computer (Digital Equipment Corp.) in conjunction with a programmable stimulator (INDEC Systems, Sunnyvale, CA) except for Figure 3. The data in Figure 3 were acquired using the ADAS-1 data acquisition system (Axon Instruments, Foster City, CA) on an IBM-compatible $80386 \mathrm{PC}(25 \mathrm{MHz})$ coupled to a TL-1-125 interface. Membrane current was sampled at $5 \mathrm{kHz}$ and filtered with an eight pole low-pass Bessel filter (Frequency Devices, I Iaverhill, MA) with a cutoff frequency $(-3 \mathrm{~dB})$ of $2.5 \mathrm{kHz}$ (whole cell) or $1 \mathrm{kHz}$ (cell attached). In whole-cell records, linear leak and capacity currents were subtracted digitally by scaling an averaged test pulse from -90 to -110 $\mathrm{mV}$. In cell-attached recordings, ensemble leak traces were accumulated either from null sweeps to the same potentials as the displayed records or from sweeps without openings with equivalent voltage steps. These sweeps were averaged and then digitally subtracted.

Calculations of the magnitude of nimodipine block were corrected for the decline in recordable current (rundown) that occurred during the course of the experiment. Although rundown was severe during the first couple of minutes of recording $(\tau=173.1 \pm 47.0 \mathrm{sec}, \pm \mathrm{SEM} ; n=3)$, the decline in current magnitude slowed during the remainder of the experiments $(46.5 \pm 5 \%, \pm \mathrm{SEM}$, measured as the magnitude of control current between 15 and 25 min $\div$ current measured at $3-4$ min after attaining whole-cell clamp; $n=6$ ). However, the half-maximal midpoint of the voltage dependence of L-channel inactivation $\left(V_{1 / 2}\right)$ did not shift with rundown or time. The mean variation in control measurements was $\Delta V_{1 / 2}=-1.9 \pm 0.58 \mathrm{mV} \mathrm{SEM}(n=5)$ over periods of $10-25 \mathrm{~min}$.

Use of dihydropyridines. Dihydropyridines degrade rapidly upon exposure to light and bind readily to plastics. Therefore, the following procedures were used minimize the loss of DHP during the experiment. Test solutions were made fresh on the day of the experiment. Glass micropipettes (Rochester Scientific, Rochester, NY) were used to dilute quantities of dihydropyridine stocks into physiological buffer contained in glass scintillation vials. Dihydropyridine stocks (1 mM; Miles, Inc., West Haven, CT) were made fresh yearly and dissolved in 100\% polyethylene glycol 400 (Baker reagent grade; average MW, 380-420) and kept refrigerated in foil-wrapped brown bottles with Teflon caps. All experiments were performed under restricted light conditions with only incidental illumination provided by sodium lamp. Perfusion of the bath was via Teflon tubing from solutions stored in glass. The experimental chamber was glass bottomed with Plexiglas sides, and the tubing and chamber were thoroughly rinsed with ethanol between experiments in which drug was used. Care was taken that no grease or Vaseline was used near the chamber since this could serve as a sink for the highly lipophilic agents and lower the drug concentration by as much as $20 \%$ in less than $1 \mathrm{~min}$ (100 nM solution; J. Chisholm, personal communication). The recording chamber was routinely exposed to ultraviolet radiation to ensure breakdown of drug, and agar bridges were discarded if exposed to drug. Nimodipine was either added directly to the bath or perfused in a recording solution. A concentration of solvent $10 \times$ greater than the largest concentration used in this study had no effect on inward calcium channel current clicited from cither hyperpolarized or depolarized potentials.

\section{Results}

\section{Voltage dependence of high-threshold current}

In order to determine the affinity of DHP inhibition of highthreshold calcium channel current in rabbit DRG neurons, it was first necessary to establish recording conditions under which different components of calcium channel currents could be clearly separated. The identification of neuronal calcium channel current arising from multiple populations of channels has in the past relied on variations in holding potential $\left(V_{H}\right)$ and test potential $\left(V_{t}\right)$ to separate kinetically distinct current components (Carbone and Lux, 1984; Nowycky et al., 1985a; Fox et al., 1987a). For example, low-threshold T-type calcium channel current activates with weak test depolarization and inactivates with depolarized holding potentials. Figure $1 B$ demonstrates that T-type current could be separated from high-threshold currents in rabbit DRG neurons by changes in holding potential (Carbone and Lux, 1984; Fox et al., 1987a; Schroeder et al., 1990b). Low-threshold current activated by weak test depolarization ( $V_{t}=-30 \mathrm{mV}$; Fig. $1 B 1$, inset current records) inactivated with a half-maximal midpoint $\left(V_{V_{2}}\right)$ of $-70.0 \mathrm{mV}$ (Fig. $1 B$, open triangles; the average $V_{1 / 2}$ for $\mathrm{T}$-type calcium channel current in seven cells was $-67.6 \pm 1.0 \mathrm{mV}, \pm$ SEM). Unlike T-type calcium channel current, L-type calcium channel current is more resistant to depolarized holding potentials and activates with strong depolarization (Tsien et al., 1988) in parallel with other types of neuronal high-threshold calcium currents (Fox et al., 1987a; Lipscombe et al., 1989; Regan et al., 1991). Of the additional types of high-threshold current, the best characterized

Table 2. Whole-cell pipette solution (mM)

\begin{tabular}{lllllllll} 
Solution & $\mathrm{CsCl}$ & TBA-Cl & $\mathrm{CaCl}_{2}$ & $\mathrm{MgCl}_{2}$ & ATP & HEPES & BAPTA & EGTA \\
\hline A & 108 & 10 & 0.9 & 6 & 5 & 20 & 11 & - \\
B & 130 & 10 & 0.9 & 2 & 1 & 10 & - & 11 \\
\hline
\end{tabular}



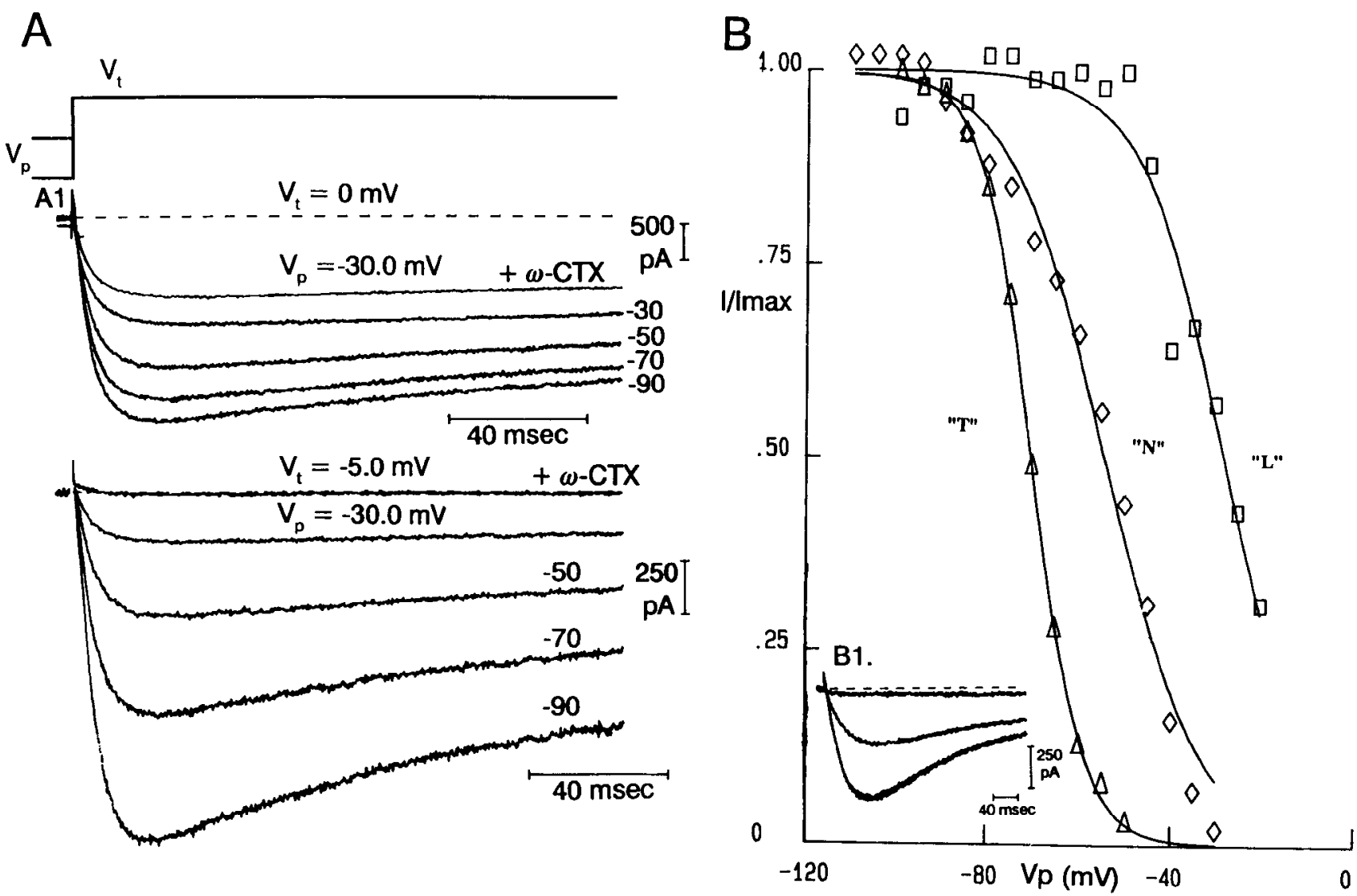

Figure 1. Al, High-threshold current requiring strong depolarization to inactivate: current elicited upon step depolarization to $0 \mathrm{mV}$ from holding potentials $\left(V_{n}\right)$ of $-90,-70,-50$, and $-30 \mathrm{mV}$ (bottom to top, respectively) in the absence (second trace from top) and presence of $\omega$-CTX (top trace). Cell \#0405B; diameter, $41.0 \mu \mathrm{m} ; 21.9^{\circ} \mathrm{C}$. Bath solution B (Table 1), pipette solution B (Table 2). Also shown are typical high-threshold currents half-maximally inactivating near $-55 \mathrm{mV}$ (bottom ensemble current traces; $V_{1 / 2}=-58.6 \mathrm{mV}$ ): current elicited by step depolarization, $V_{t}=-5 \mathrm{mV}$ following a varied prepulse potential $\left(V_{P} ;-90,-70,-50\right.$, and $-30 \mathrm{mV}$; largest magnitude trace to smallest, respectively) with the top trace at the zero current level demonstrating maximal inhibition by $\omega$-CTX. Cell \#0405A; diameter, $38 \mu \mathrm{m} ; 21.9^{\circ} \mathrm{C}$. Bath solution B (Table 1 ); pipette solution B (Table 2). $B$, Steady-state availability curves. Low- and high-threshold currents were elicited by step depolarization $\left(V_{t}\right)$ following $8 \mathrm{sec}$ prepulses to various holding potentials $\left(V_{p}^{\prime}\right)$ and plotted versus the magnitude of normalized current $\left(I / I_{\max }\right)$ at the peak $t \cong 10$ msec or at $t$ $=160 \mathrm{msec}$ and fit by the equation $I / I_{\max }=\left\{1+\exp \left[\left(V p-V_{y_{2}}\right) / k\right]\right\}^{-1}$, with $k$ being the slope factor. Open triangles, Unique low-threshold current: $V_{t}=-40 \mathrm{mV} ; V_{1 / 2}=-70.2 \mathrm{mV} ; k=5.6$; cell \#0117b; diameter, $29.0 \mu \mathrm{m} ; 23.0^{\circ} \mathrm{C}$. Bath solution B (Table 1), pipette solution B (Table 2). Open diamonds, High-threshold current with a more negative inactivation range: $V_{t}=-10.0 \mathrm{mV} ; V_{1,2}=-54.4 ; k=10.2$. Cell \#0802A; diameter, 33.0 $\mu \mathrm{m} ; 23.0^{\circ} \mathrm{C}$. Open squares, high-threshold current with a less negative inactivation range; $V_{t}=-10.0 \mathrm{mV} ; V_{1 / 2}=-28.6 \mathrm{mV} ; k=10.0$. Cell \#0802B; diameter, $38.0 \mu \mathrm{m} ; 23.3^{\circ} \mathrm{C}$. For both high-threshold current cells, the bath solution was A (Table 1) and the pipette solution was A (Table 2). Inset $B 1$, Typical low-threshold currents are displayed at various holding potentials [ $V_{H}=-100$ and -90 (lower traces superimpose), $-70 \mathrm{mV}$ (middle trace), and $-50 \mathrm{mV}$ (upper trace); $V_{1}=-40 \mathrm{mV}$. Cell \#0117B; diameter, $29.0 \mu \mathrm{m} ; 23.0^{\circ} \mathrm{C}$. Bath solution B (Table 1), pipette solution B (Table 2).

in DRG neurons is $\omega$-CTX-sensitive N-type calcium channel current. Although L- and N-type current were successfully separated by differences in kinetics in cultured chick DRG neurons (Fox et al., 1987a), this method is only useful if the voltage dependence of activation and inactivation of the different types of high-threshold calcium channel currents are consistently and significantly different. In rabbit DRG neurons, it was difficult to identify the presence of multiple high-threshold channel types based on the time course of calcium current decay during the test pulse $\left(V_{t}, 160 \mathrm{msec}\right)$. High-threshold calcium channel current inactivated slowly and often appeared to decay with a single exponential. Plots of peak calcium channel current magnitude against various prepulse potentials ( $V_{p}$, availability curves) suggested the presence of more than one type of high-threshold calcium channel current since in many cells availability curves were poorly fit by a single Boltzmann function (Schroeder et al., 1990a). Thus, we used the presence of multiple components in the availability curves recorded for each cell to predict the presence of multiple types of calcium channel currents.

In some cells, high-threshold current appeared to arise from a homogeneous population of high-threshold channels as judged by the presence of a single Boltzmann function in the availability curves. In these cells, differences in the voltage dependence of half-maximal channel inactivation $\left(V_{1 / 2}\right)$ were used to characterize the type of high-threshold calcium channel current underlying the macroscopic whole-cell current.

Figure $1 A$ shows results from two cells, isolated during the same dispersal and studied using the same test solutions with $5 \mathrm{~mm}$ barium as the charge carrier, exhibiting two distinct types of high-threshold current. Figure $1 A l$ (upper current traces) shows one type of high-threshold calcium channel current recorded from a cell with sustained inward current that was very resistant to voltage-dependent inactivation $\left(V_{1 / 2}=-27.2 \pm 1.2 \mathrm{mV}\right.$, \pm SEM; $n=7$ ). In this and three other cells exhibiting this type 

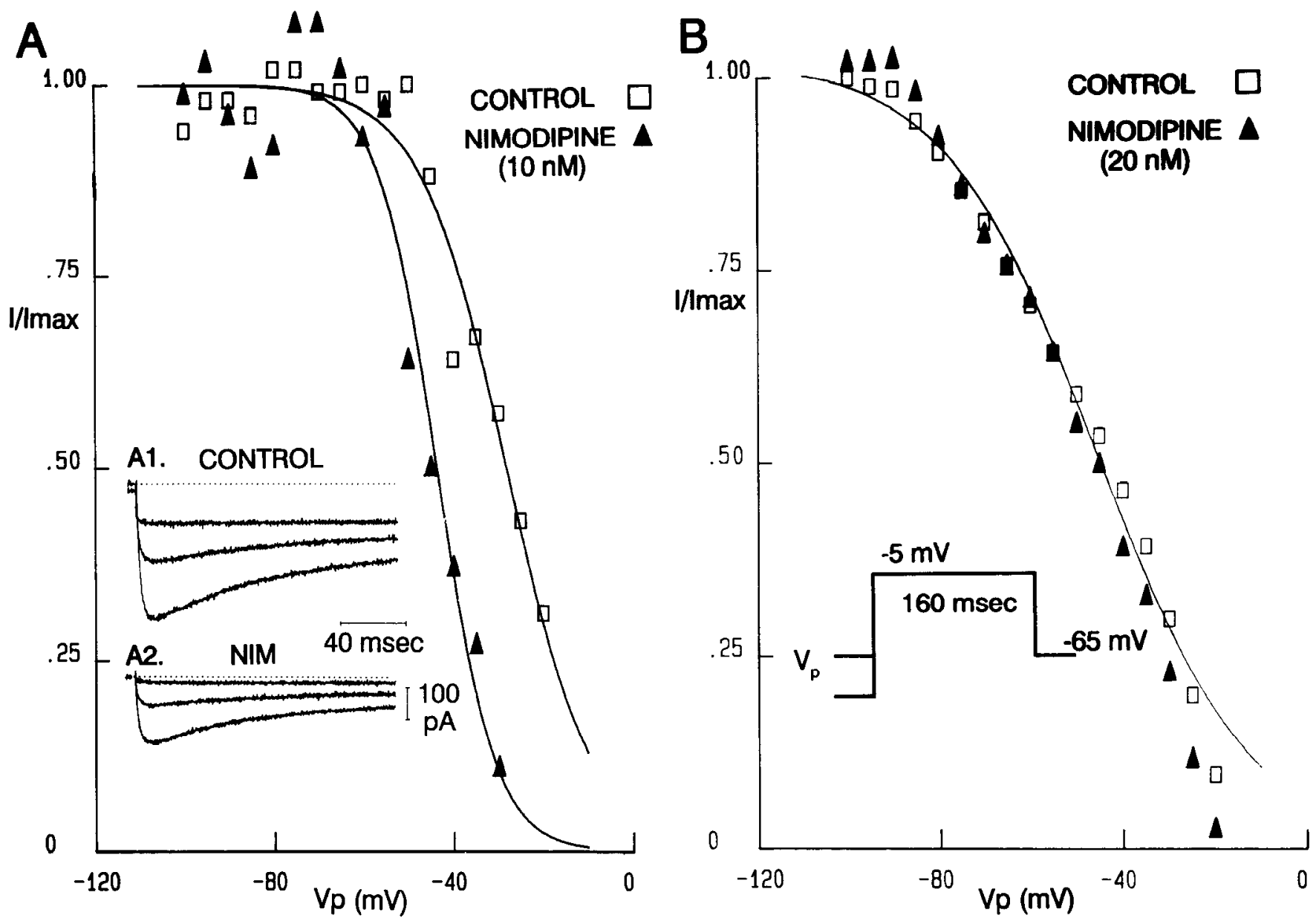

Figure 2. A, Voltage-dependent nimodipine block of high-threshold current. $A$, Inward current was elicited by a 160 msec test depolarization to $-10 \mathrm{mV}$ following an $8 \mathrm{sec}$ prepulse both in control (open squares) and in the presence of nimodipine (solid triangles). Currents measured after $160 \mathrm{msec}$ of test depolarization are plotted versus a varied prepulse potential $\left(V_{p}\right)$ in control (open squares; $I_{\max }=-172.6 \mathrm{pA} ; V_{1 / 2}=-27.8 \mathrm{mV} ; k$ $=9.11$ ) versus nimodipine (solid triangles; $I_{\max }=-101.9 ; V_{1,}=-43.7 \mathrm{mV} ; k=6.4$ ). Binding to the inactivated state was calculated using the difference in the $V_{1 / 2}$ with the averaged slope factors (Bean, 1984) by the equation $\Delta V=-15.9 \mathrm{mV}=k \ln \left[\left(1+(\mathrm{drug}) / K_{I}\right) /\left(1+(\mathrm{drug}) / K_{R}\right)\right]$; thus $K_{I}=$ $1.24 \mathrm{~nm}$. Same cell as Figure $1 B$ (open squares). Inset, In the absence $(A I)$ and presence $(A 2)$ of nimodipine, the displayed peak current traces were recorded from potentials $-90,-70$, and $-30 \mathrm{mV}\left(V_{t}=-10 \mathrm{mV}\right)$. Broken line represents zero current level. $B$, High-threshold current insensitive to $20 \mathrm{nM}$ nimodipine. Control (open squares; $I_{\max }=-853.1 \mathrm{pA} ; V_{\mathrm{V}}=-45.8 \mathrm{mV} ; k=15.1$ ) is plotted against nimodipine (solid triangles; $I_{\mathrm{max}}=$ $-361.7 \mathrm{pA} ; V_{1 / 2}=-47.2 \mathrm{mV} ; k=12.9$ ). Cell \#0201A; diameter, $37.5 \mu \mathrm{m} ; 22.2^{\circ} \mathrm{C}$. Bath solution B (Table 1), pipette solution B (Table 2).

of calcium channel current $\omega$-CTX (McCleskey et al., 1987) at 5-20 $\mu \mathrm{M}$ had little or no blocking action (Fig. 1A1, uppermost current record). The lower ensemble current traces (Fig. $1 A$ ) are records from a cell with a different type of calcium channel current that was more sensitive to voltage-dependent inactivation $\left(V_{1 / 2}=-56.9 \pm 2.0 \mathrm{mV}, \pm \mathrm{SEM} ; n=8\right)$ that was blocked by $\omega$-CTX (uppermost current record at zero current level). Currents such as those shown in Figure $1 A$ were plotted as current magnitude versus a varied prepulse potential and could be fit by a single Boltzmann function (Fig. $1 B$ : open squares, $V_{1 / 2}=-28.6 \mathrm{mV}$; open diamonds, $V_{1 / 2}=-54.4 \mathrm{mV}$ ).

\section{Voltage dependence of nimodipine block}

The effect of nimodipine on both types of high-threshold current was studied over a broad range of voltages in the absence and presence of nimodipine. Figure $2 A$ demonstrates a typical response to nimodipine in cells with mostly L-type calcium channel current (e.g., Fig. 1AI). L-type current was potently inhibited by nimodipine $(n=8)$. The magnitude of high-threshold current (after 150-160 mscc of test depolarization) was plotted versus various prepulse potentials in the absence (open squares) and presence of nimodipine ( $10 \mathrm{~nm}$; solid triangles). Consistent with previous observations in cardiac muscle cells (Bean, 1984; Sanguinetti and Kass, 1984), depolarized holding potentials promoted nimodipine block such that the steady-state availability curve shifted to more hyperpolarized potentials $\left(\Delta V_{1 / 2}=-15.9\right.$ $\mathrm{mV}$ ). In cells with mainly L-type channels, calcium channel current elicited from a holding potential of $-30 \mathrm{mV}$ in control represented $52.1 \pm 6 \%(n=5)$ of total elicitable calcium channel current, while in the presence of nimodipine, current elicited from $-30 \mathrm{mV}$ represented $18.4 \pm 7 \%(n-5)$ of the total. The shift of the steady-state availability curve for L-type calcium channels in response to nimodipine (10 $\mathrm{nM}$; assessed 5-7 min after application) was $-13.9 \pm 2.0 \mathrm{mV}$. Similar high-affinity, voltage-dependent nimodipine block was also demonstrated with calcium in place of barium as the charge carrier (data not shown). Assuming 1:1 binding of nimodipine to the resting and inactivated states, the macroscopic dissociation rate constant for binding of nimodipine to the inactivated state of the L-type calcium channel $\left(K_{l}\right)$ was calculated to be $5.3 \mathrm{~nm}(n=8)$. The 
A
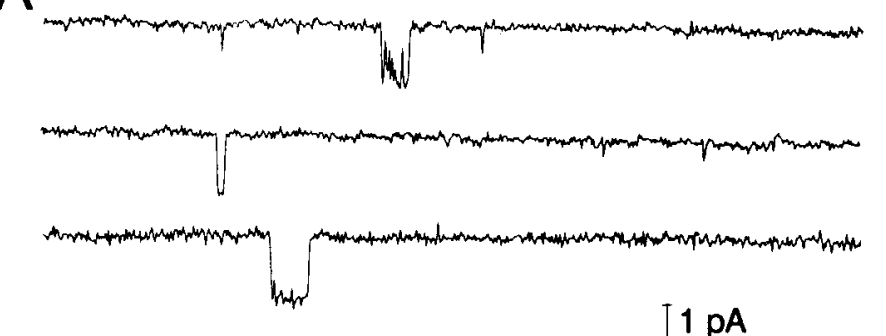

B
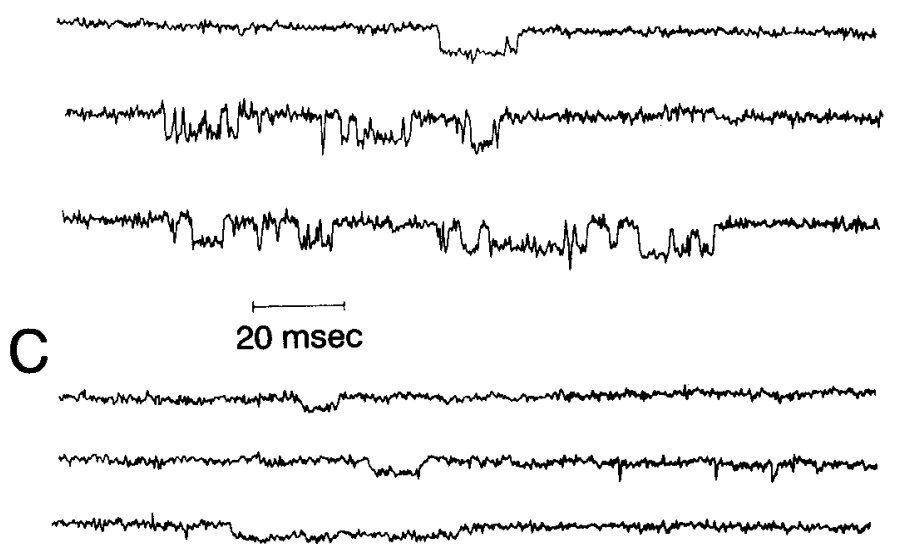

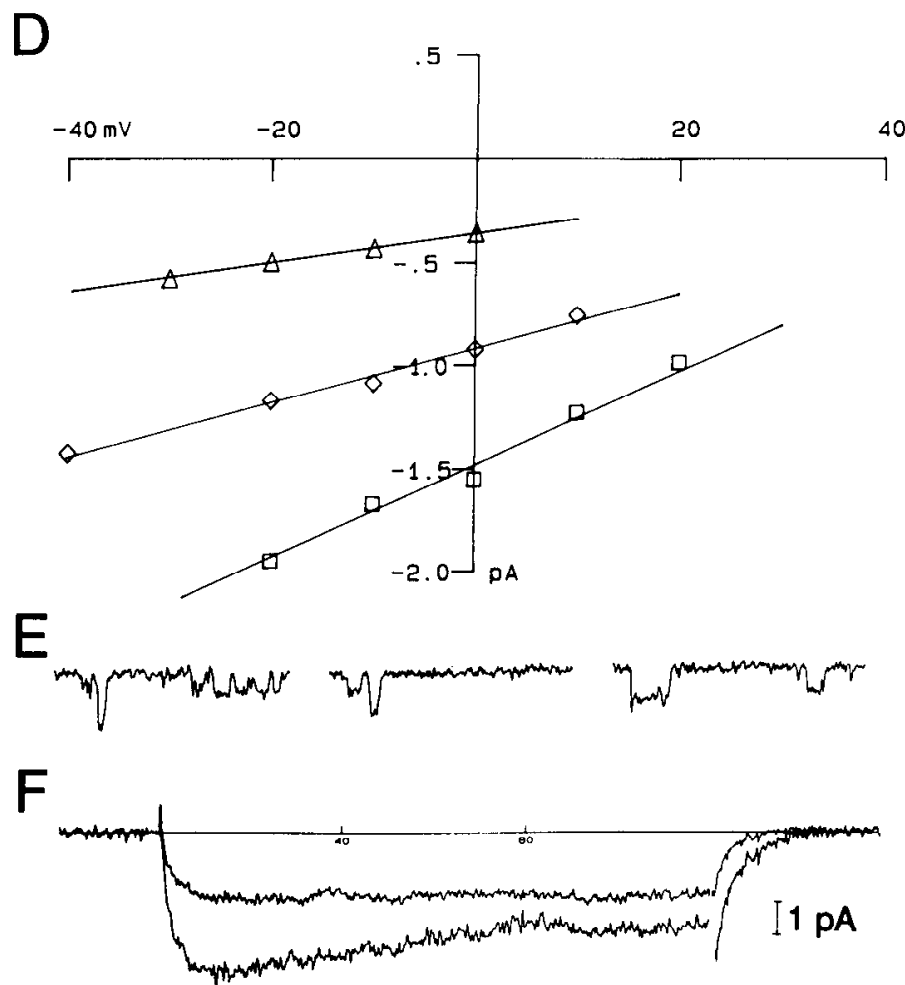

Figure 3. Multiple single-channel conductances in DRG neurons. A, Large conductances recorded at a test potential of $-20 \mathrm{mV}$ from holding potentials of -60 [top and middle traces (cell \#0K28A; diameter, $38.5 \mu \mathrm{m} ; 21.4^{\circ} \mathrm{C}$ )] or $-90 \mathrm{mV}$ (bottom trace) in the presence of $50 \mathrm{nM}$ BAY K 8644 (cell \#B02C04; diameter, $36.0 \mu \mathrm{m} ; 21.9^{\circ} \mathrm{C}$ ). B. Medium conductances from a holding potential of $-90 \mathrm{mV}$ a test potential of $-20 \mathrm{mV}$. Top trace: cell \#0K28B; diameter, $31.0 \mu \mathrm{m} ; 21.4^{\circ} \mathrm{C}$. Middle and bottom traces: cell \#L14A03; diameter, $46.0 \mu \mathrm{m} ; 21.9^{\circ} \mathrm{C}$. C, Small conductances available with hyperpolarized holding potentials activated by test depolarization to $-20 \mathrm{mV}$. Cell $\# 0 \mathrm{~K} 28 \mathrm{~A}$; diameter, $38.5 \mu \mathrm{m} ; 21.4^{\circ} \mathrm{C}$. $D$, Average magnitudes of single-channel conductances plotted versus test potential. Triangles, $7.4 \mathrm{pS}$; diamonds, $13.1 \mathrm{pS}$; squares, $24.1 \mathrm{pS}$. E, Large and medium conductances available from depolarized holding potentials. $F$, Averages of 45 consecutive sweeps from holding potentials of $-90 \mathrm{mV}$ (lower trace) and $-50 \mathrm{mV}$ (upper trace) elicited by test depolarization to $+20 \mathrm{mV}$. Cell \#L14A03.

dissociation rate constant for resting-state block $\left(K_{R}\right)$ used to determine the dissociation constant of the inactivated state of the channel in the presence of nimodipine $\left(K_{t}\right)$ was $70 \mathrm{~nm}$ (e.g., for nisoldipine; see Nelson and Worley, 1989). Calculations of $K_{R}$ were made from currents elicited from hyperpolarized potentials in the presence of 20-400 nM nimodipine $(n=7)$.

Little additional block of calcium channel current was observed when concentrations of nimodipine were increased from 20 to $200 \mathrm{~nm}$ even at depolarized potentials. The presence of a DHP-resistant component to the calcium channel current is consistent with other observations in a variety of neuronal preparations (Mogul and Fox, 1991; Regan, 1991; Regan et al., 1991). Clearly, calculations of resting-state block of high-threshold calcium channel current will be strongly influenced by the presence and magnitude of calcium channels that differ in their sensitivity to DHPs.

When the majority of high-threshold calcium channel current inactivated with a half-maximal midpoint near $-55.0 \mathrm{mV}$, nimodipine ( $20 \mathrm{~nm}$ ) had little or no effect at most potentials (Fig. $2 B$ ). The only noticeable effects of nimodipine were observed at the most depolarized potentials $\left(V_{p}=-20 \mathrm{mV}\right)$, which could easily be due to a small contribution of L-type channels to the inward current. In three cells exhibiting this type of calcium channel current, $5 \mu \mathrm{M} \omega$-CTX completely inhibited the highthreshold current. It was concluded that the nimodipine-insensitive, $\omega$-CTX-sensitive current arose from the activation of neuronal high-threshold N-type calcium channels.

\section{Multiple single-channel conductances}

Cell-attached patch recording offers the least ambiguous way to study the underlying single-channel currents of whole-cell calcium channel currents (Carbone and Lux, 1984; Nowycky et al., 1985a; Fox et al., 1987b). Single-channel currents from DRG cells $(n=17)$ were recorded in cell-attached patches using 115 тм barium as the charge carrier. Figure $3 A-C$ demonstrates three different types of calcium channel currents that were consistently observed in DRG cells recorded at the same test potential, $V_{t}=-20 \mathrm{mV}$. In Figure $3 A$, relatively long openings of a large-conductance channel, which usually opened for only brief periods of time, are plotted. These large-conductance openings remained readily available to open when elicited from depolarized holding potentials and were sensitive to the DHP agonist BAY K 8644 (50 nм; $n=5$ ). In Figure $3 B$, a smaller conductance channel is shown that opened more readily from hyperpolarized holding potentials but often remained available for opening when elicited from depolarized holding potentials. In Figure $3 C$, a small conductance channel is shown that required hyperpolarized holding potentials to remain available for opening. Figure $3 D$ shows the average amplitude of at least 10 well-resolved openings for each channel type plotted against test potential and fit by linear regression to provide estimates of single-channel conductances of $24.1 \mathrm{pS}$ (Fig. $3 A$; open squares), $13.1 \mathrm{pS}$ (Fig. $3 B$; open diamonds), and $7.4 \mathrm{pS}$ (Fig. $3 C$; open triangles). Although the single-channel currents shown in Figure $3 A-C$ were 

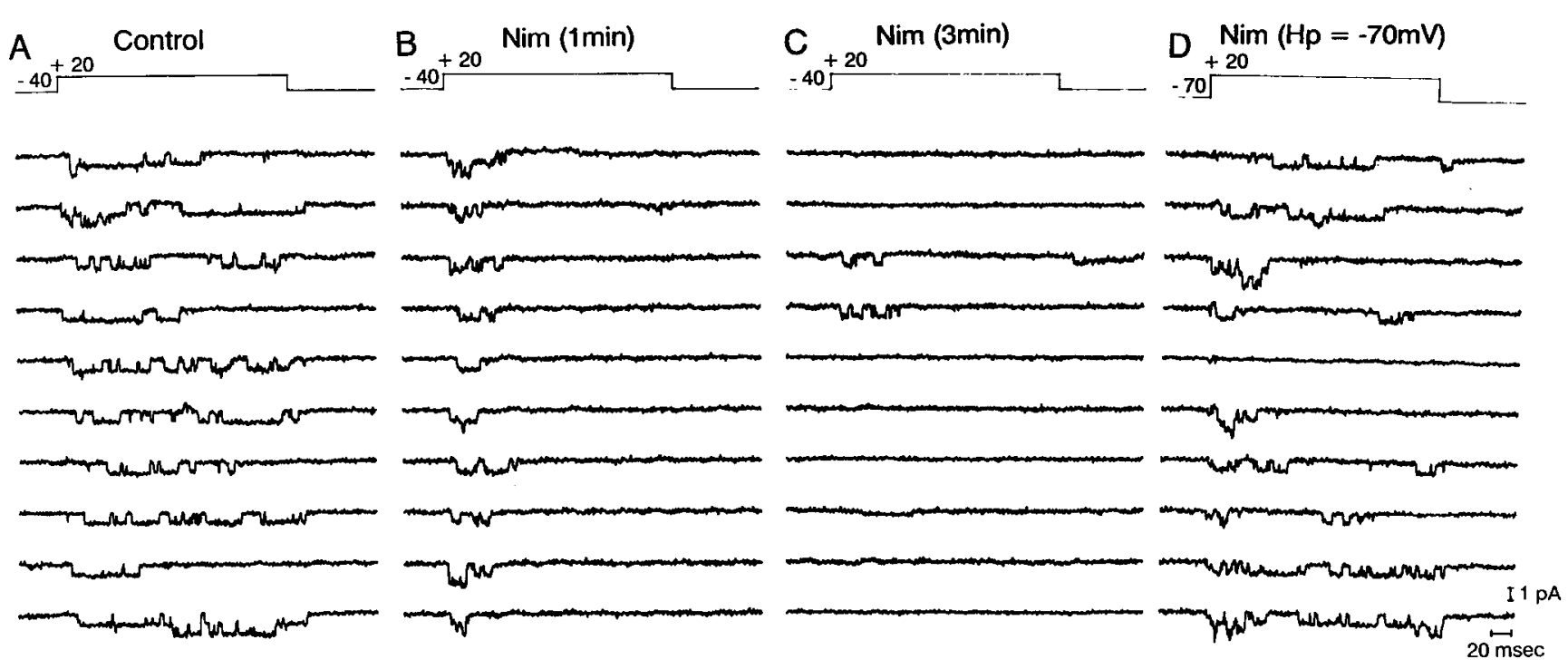

Figure 4. Nimodipine block reversed by hyperpolarization. $A$, The series of recordings in the presence of 50 nM BAY K 8644 show numerous channel openings $\left(V_{H}=-40 \mathrm{mV} ; V_{t}=+20 \mathrm{mV}\right) . B$ was recorded $1 \mathrm{~min}$ after addition of nimodipine (50 nM) to the bath. $C$ demonstrates the effect of nimodipine at $t=3 \mathrm{~min}$ as the number of null sweeps has increased $4 \times$. In $D$, the membrane potential was hyperpolarized $\left(V_{H}=-70\right.$ $\mathrm{mV}$ ) to reverse voltage-dependent nimodipine block. Cell \#B02C02; diameter, $36.0 \mu \mathrm{m} ; 21.9^{\circ} \mathrm{C}$.

elicited by voltage steps from hyperpolarized holding potentials, it was routinely possible to elicit the $24.1 \mathrm{pS}$ and $13.1 \mathrm{pS}$ conductance types after many minutes at steady holding potentials as depolarized as $-40.0 \mathrm{mV}$ (Fig. $3 E$ ). Holding potentials of $-40.0 \mathrm{mV}$ completely inactivated the $7.4 \mathrm{pS}$ conductance. Ensemble single channel current records of the $13.1 \mathrm{pS}$ conductance were constructed from the average of 45 consecutive traces recorded from the same cell-attached patch as Figure $3 B(0.2 \mathrm{~Hz}$; $V_{t}=+20 \mathrm{mV}$ ). Average currents from holding potentials of $-90.0 \mathrm{mV}$ (Fig. $3 F$, lower trace) and $-50.0 \mathrm{mV}$ (Fig. $3 F$, upper trace) demonstrated half-maximal inactivation near $-50.0 \mathrm{mV}$, yet a sustained current could be elicited from the depolarized potential of $-50 \mathrm{mV}$. The $13.1 \mathrm{pS}$ conductance is similar to $\mathrm{N}$-type channels previously described in other neurons and likely underlies the $\omega$-CTX-sensitive whole-cell current. Like N-type channels in sympathetic neurons (Plummer et al., 1989), the $\mathrm{N}$-type channel described here in rabbit DRG can be remarkably resistant to voltage-dependent inactivation compared to the N-type channel of chick DRG (Fox et al., 1985a,b) and can contribute a sustained current during strong test depolarizations. The $24.1 \mathrm{pS}$ and $7.4 \mathrm{pS}$ conductances are characteristic of L-type and T-type calcium channels previously described in sensory neurons (Carbone and Lux, 1984; Nowycky et al., 1985a; Fox et al., 1987a).

\section{Nimodipine block of L-type channels}

The selectivity and voltage dependence of nimodipine block were demonstrated in single-channel recordings. In Figure 4, a DRG cell was held depolarized $\left(V_{H}=-40 \mathrm{mV}\right)$ to isolate L-type channel activity and favor voltage-dependent block by nimodipine. The cell was pretreated by adding $50 \mathrm{~nm}$ BAY $\mathrm{K} 8644$ to the bath. Records were obtained after prolonged L-channel openings were established in response to agonist pretreatment (Nowycky et al., 1985b). Figure $4 A$ shows a patch containing openings of two L-type channels elicited by step depolarization to $+20 \mathrm{mV}$. Under these conditions, openings of single L-type channels could be recorded in the absence of rundown for many tens of minutes. One minute after the addition of nimodipine ( $50 \mathrm{nM} ; n=2)$ to the bath, single-channel openings were only observed very early in the test depolarization (Fig. $4 B$ ). After 3 min in the presence of nimodipine, channel openings were markedly suppressed throughout the test pulse with few detectable channel openings (Fig. $4 \mathrm{C}$ ). The inhibitory effect of nimodipine was shown to be voltage dependent (Fig. $4 D$ ). When the holding potential was hyperpolarized $\left(V_{H}=-70 \mathrm{mV}\right)$, nimodipine block was relieved and single-channel openings were once more elicited by step depolarization to $+20 \mathrm{mV}$. Nimodipine ( $50 \mathrm{nM}$ ) inhibition was also observed in cell-attached patch without prior exposure to Bay K 8644 (McCarthy, 1989).

\section{Dose dependence of neuronal L-type channel block by nimodipine}

Several factors complicated the study of the concentration dependence of nimodipine block. These included (1) the existence of multiple high-threshold currents, (2) high-affinity block by nimodipine of channels in the resting state, and (3) rundown of calcium channel activity during the time course of whole-cell recording. To overcome these problems, cell-attached patch recordings were obtained under conditions that isolated L-type channel activity from other channel types and that promoted voltage-dependent block by nimodipine. Figure 5 shows results from a cell-attached patch containing only L-type channels to which increasing concentrations of nimodipine were added. This patch contained at least three L-type channels whose activity showed no rundown and remained stable for the duration of the experiment $(2.5 \mathrm{hr})$. All recordings shown in Figure 5 were obtained in the presence of 30 nM BAY R 5417 to promote long openings of L-type channels (Nowycky et al., 1985b). BAY R 5417 is the agonist (-) $4 S$ enantiomer of BAY K 8644 (Hess et al., 1984) and at low concentrations does not exhibit the antagonistic properties observed with the racemic mixture, BAY K 8644 (McCarthy and Cohen, 1986; Kass, 1987).

Having established a stable series of L-channel current recordings, elicited by step depolarizations to $+20 \mathrm{mV}$, the cell 
A
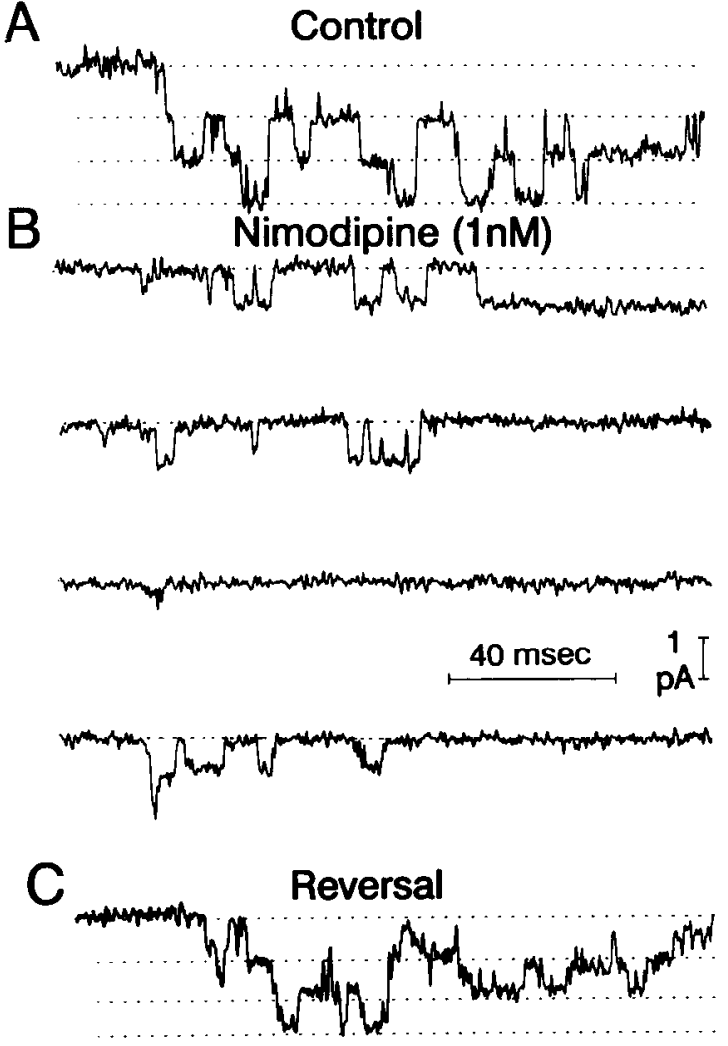

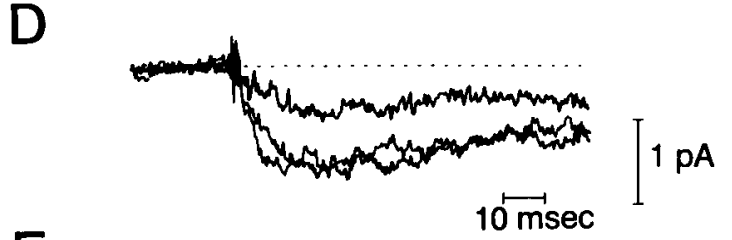

$E$

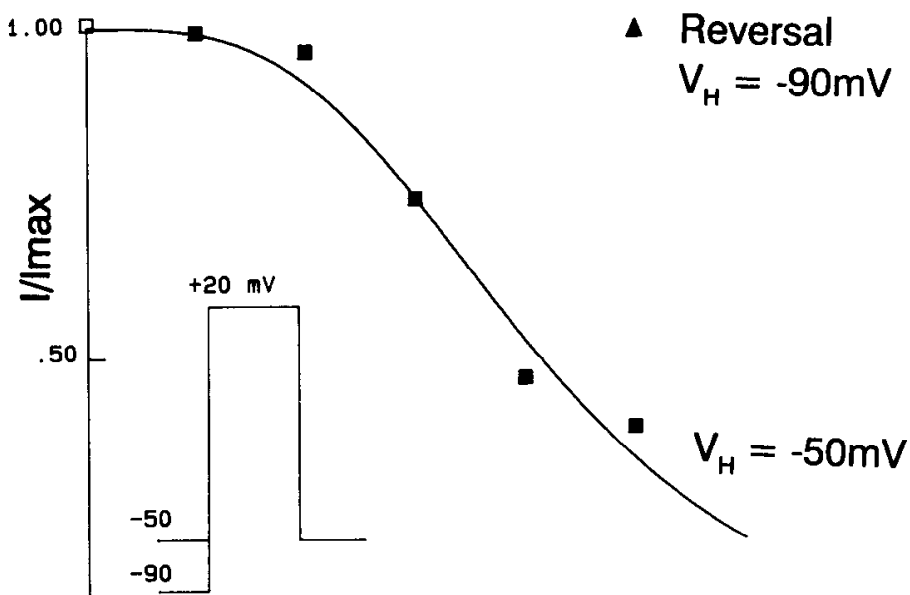

.001

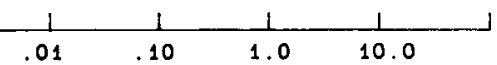

NIMODIPINE (nM)

Figure 5. Nimodipine single-channel dose-response curve. A, L-type channels pretreated with Bay R 5417 (-) $4 S$ enantiomer of BAY K 8644 ; $30.0 \mathrm{nM})$ were activated by strong depolarization $\left(V_{t}=+20 \mathrm{mV} ; 0.125 \mathrm{~Hz}\right)$ from $V_{H}=-50 \mathrm{mV}$. $B$, In the presence of $1 \mathrm{nM}$ nimodipine, four consecutive sweeps demonstrate that channel activity was much reduced and sweeps without recordable current (null, third sweep) appeared for the first time during the course of the experiment. $C$, Reestablishment of sweeps with multiple channel openings occurred within 1 min of the return to hyperpolarized holding potentials $\left(V_{H}=-90 \mathrm{mV}\right)$ in the continued presence of $10 \mathrm{~nm}$ nimodipine. $D$, Averages of macroscopic singlechannel currents ( 25 consecutive sweeps) demonstrated that current in the presence of 1 nM nimodipine (upper trace) was much reduced when compared to the control level $\left(V_{H}=-50 \mathrm{mV}\right)$ or the level recorded after hyperpolarization in the presence of $10 \mathrm{~nm}$ nimodipine $\left(V_{H}=-90 \mathrm{mV}\right)$ shown as the two superimposible lower traces. The amount of total elicitable current obtained from $V_{H}=-90 \mathrm{mV}$ in nimodipine (10 nM) had declined by $8 \%$ compared with that elicited in control. Leak sweeps, used for records containing numerous single-channel openings, were generated from sweeps of comparable voltage steps between negative potentials that did not elicit openings. $E$, The magnitudes of averaged currents were normalized $\left(I_{\max }=-1.19 \mathrm{pA}\right)$ to the average of valucs measurcd in control $\left(V_{H}=-50 \mathrm{mV}\right)$ and in the presence of 1 and $10 \mathrm{pM}$ nimodipine and plotted versus the log concentration of nimodipine as a dose-response curve. Holding potential, $-50 \mathrm{mV}$, and test potential, $+20 \mathrm{mV}$, for control (open square) and nimodipine (solid squares). Solid triangle is the amount of current recordable from $V_{H}=-90 \mathrm{mV}$, and normalized to the amount from $-50 \mathrm{mV}$. Cell \#K09A01; diameter, $41.0 \mu \mathrm{m} ; 22.2^{\circ} \mathrm{C}$.

was exposed to increasing concentrations of nimodipine ( 1 pM to $10 \mathrm{~nm}$ ) while the patch was held at the depolarized potential of $-50 \mathrm{mV}$. Individual sweeps of L-channel currents for control (Fig. $5 A$ ) and $1 \mathrm{nM}$ nimodipine (Fig. $5 B$ ) elicited from $V_{H}=$ $-50 \mathrm{mV}$, and $10 \mathrm{~nm}$ nimodipine elicited from $-90 \mathrm{mV}$ (Fig. $5 C$ ) are shown together with their corresponding average singlechannel currents (Fig. $5 D$ ). At least 25 consecutive sweeps were obtained at each concentration of nimodipine 3 min after the concentration change. Figure $5 E$ shows a plot of average single L-type channel amplitudes in the presence of increasing concentrations of nimodipine. Current amplitudes were normalized to the average of control current in the absence of nimodipine and current that had remained largely unchanged in the presence of 1 and 10 pM nimodipine. The data were fit by a $1: 1$ doseresponse curve with a $K_{I}$ of $1.4 \mathrm{nM}$ at a holding potential of $-50 \mathrm{mV}$. A similar experiment performed without agonist pretreatment resulted in an estimated $K_{I}=0.6 \mathrm{nM}\left(V_{H}=-40 \mathrm{mV}\right)$. At the start and end of the experiment, a series of L-channel currents was also elicited by step depolarizations from a more hyperpolarized holding potential of $-90 \mathrm{mV}$. The magnitude of the averaged $\mathrm{I}$-channel currents activated from $V_{H}=-90$ $\mathrm{mV}$ in control was no different from that elicited from $V_{H}=$ $-50 \mathrm{mV}$ as expected for a patch containing only L-channels. In addition, and most significantly, the magnitude of the L-channel current activated from $V_{H}=-90 \mathrm{mV}$ in the presence of 10 nM nimodipine (solid triangle, Fig. $5 E$ ) was no different from control. The remarkable stability of the cell-attached patch recording alleviating complicating factors such as calcium current rundown and ruling out contributions to the calcium current from other types of high-threshold currents provides a powerful demonstration of the voltage-dependent reversibility of lowconcentration nimodipine block of L-type calcium channels.

\section{Discussion}

The major finding of this article is that in rabbit DRG neurons there is a large component of high-threshold calcium channel current that can be inhibited, with high affinity $\left(K_{I}=5.3 \mathrm{~nm}\right)$, by nimodipine. This DHP-sensitive calcium channel current is 
not inhibited by $\omega$-CTX (Aosaki and Kasai, 1989; Scroggs and Fox, 1991) and is best characterized as an L-type calcium channel. We have also identified a DHP-insensitive high-threshold calcium channel current that was potently inhibited by $\omega$-CTX and is best characterized as an $\mathrm{N}$-type calcium channel. This study thus supports the concept of multiple types of high-threshold calcium channel currents present in neurons (Nowycky et al., 1985a) that can be separated by differences in pharmacological sensitivity (Jones and Jacobs, 1990).

Our finding that the L-type calcium channel current in rabbit sensory neurons is inhibited by nanomolar concentrations of nimodipine is important since neuronal calcium channels are typically thought not to be inhibited with high affinity by DHPs. The conviction that neuronal L-type calcium channels are relatively insensitive to DHPs likely originated from the fact that DHPs are not effective inhibitors of classical neurotransmitter release in many systems (Middlemiss and Spedding, 1985; Perney et al., 1986). Inhibitory effects of DHPs on peptide neurotransmitter release have been reported under depolarized conditions that favor DHP binding. Substance $P$ release in sensory neurons was shown to be inhibited by nimodipine (Perney et al., 1986) and nifedipine (Rane et al., 1987) when evoked by high- $\mathrm{K}^{+}$depolarization but not when evoked by electrical stimulation. The ineffectiveness of DHPs to inhibit transmitter release from many systems now appears to be due to the presence of multiple types of high-threshold calcium channel currents that dominate over L-type channels in controlling classical neurotransmitter release (Perney et al., 1986). For example, Hirning et al. (1988) demonstrated that $\omega$-CTX-sensitive N-type calcium channels, not DHP-sensitive L-type channels, dominate in the release of norepinephrine from sympathetic neurons.

In this study, we have readdressed the issue of whether L-type calcium channels of neurons are inhibited with high affinity by DHPs (see also Boland and Dingledine, 1990). Our results suggest that neuronal L-type calcium channels possess a high-affinity DHP binding site that is functionally similar to that described in cardiac and smooth muscle. We estimate that nimodipine inhibits L-type calcium channel currents in rabbit sensory neurons with a $K_{D}$ for block of resting state channels $\left(K_{R}\right)$ of $70 \mathrm{nM}$. This finding suggests that concentrations of nimodipine greater than $100 \mathrm{~nm}$ may be sufficient to suppress DHP-sensitive L-type calcium channel current completely even when elicited from hyperpolarized potentials. For example, in Figure 4 L-type calcium channel current inhibited by $50 \mathrm{~nm}$ nimodipine was restored by hyperpolarizing the membrane potential $\left(V_{H}=-70 \mathrm{mV}\right)$. However, in experiments in which concentrations of nimodipine in excess of $100 \mathrm{~nm}$ were used, hyperpolarization $\left(V_{H}=-90 \mathrm{mV}\right.$ ) failed to relieve L-channel inhibition, with the degree of inhibition seldom greater at 200 $\mathrm{nm}$ than at $20 \mathrm{~nm}$ nimodipine. Thus, increasing the concentration of DHP to greater than $100 \mathrm{~nm}$ obscured the voltage dependence of L-type channel inhibition. Further increasing the concentration of nimodipine into the micromolar range may compromise the selectivity of nimodipine for L-type calcium channels such that other types of channels are affected (Akaike ct al., 1989; Joncs and Jacobs, 1990). Even in the presence of $10 \mu \mathrm{M}$ nimodipine, however, the calcium channel current recorded in most cells is not completely suppressed (Docherty and Brown, 1986), confirming the presence of DHP-insensitive highthreshold calcium channel current.

In addition to L-type calcium channel currents, we have also identified low-threshold T-type and high-threshold N-type cur- rents in rabbit DRG cells. Low-threshold, T-type current was observed in 34 of 62 cells tested, whereas all cells tested ( $n=$ 67) possessed high-threshold current. A large component of highthreshold calcium channel current was L-type current, in agreement with results in DRG cells from other species (chick, Fox et al., 1987a; rat, Scroggs and Fox, 1991). The magnitude of L-type current was often as great as $80-90 \%$ of the total highthreshold calcium channel current $\left(V_{H}=-90 \mathrm{mV}\right)$ when measured as calcium current elicited from a depolarized holding potential of $-50.0 \mathrm{mV}$ (see Fig. $1 A I$ ), though in some cells little or no measureable L-type calcium channel current was observed. The failure to observe L-type current in some cells could be the result of rapid washout of L-type channel current in neurons (Jones and Marks, 1989), or it could reflect the presence of subpopulations of DRG cells that do not express L-type channels (Scroggs and Fox, 1991).

It was relatively easy to separate low-threshold T-type calcium channel current from high-threshold current in whole-cell recordings due to the significant difference in the voltage range over which these two groups of currents activated and inactivated. However, we were faced with several problems in trying to separate L-type currents from $\mathrm{N}$-type calcium currents for the following reasons. (1) Both $\mathrm{L}$ - and $\mathrm{N}$-type currents activated over a similar voltage rangc, rcquiring relativcly strong dcpolarizations. (2) Although the N-type channel current appeared to inactivate more readily with steady depolarizations, a significant fraction of the $\mathrm{N}$-type current was still available for activation from holding potentials close to $-40 \mathrm{mV}$ (Plummer et al., 1989). (3) The voltage dependence of DHP inhibition was similar to the voltage dependence of $\mathrm{N}$-channel inactivation, so the use of DHP antagonists to separate L-type channel currents from N-type channel currents in whole-cell recordings was complex (Fig. 2B). (4) Finally, a small (less than $7 \%$ of the total current) but significant fraction of the whole-cell high-threshold calcium channel current recorded in rabbit sensory neurons was nimodipine insensitive (at $200 \mathrm{nM}$ ) and $\omega$-CTX insensitive (at $10 \mu \mathrm{M})$, suggesting the presence of an additional type of calcium channel current (see Mogul and Fox, 1991; Regan et al., 1991).

We were, however, fortunate in this study to have identified a number of cells that predominantly expressed a single population of high-threshold calcium channel current as judged by the presence of a single Boltzmann function in the voltage dependence of high-threshold channel inactivation. In total, we observed 12 cells that expressed a predominately L-type channel current (nimodipine sensitive, $\omega$-CTX insensitive); 9 cells that expressed a predominately $\mathrm{N}$-type channel current ( $\omega$-CTX sensitive, nimodipine insensitive), and 5 cells that expressed an additional high-threshold current that was resistant to both nimodipine and $\omega-C T X$. It is possible that subpopulations of DRG cells exist that differentially express calcium channel types. Indeed, Scroggs and Fox (1991) have recently shown that small DRG cells from rat consistently express a large component of L-type calcium channel current. Since we did not observe a similar correlation between cell size and the relative magnitude of L-type channel expression in rabbit DRG cells, it would be of interest to know if small DRG cells from rat have L-type calcium channel current that could be more readily tested for block by nanomolar concentrations of nimodipine.

Accumulating evidence supports the idea that nimodipine will be clinically valuable in the therapy of CNS disorders (Scriabine, 1987; Scriabine et al., 1989). For example, nimodipine can apparently enhance learning and memory in aging rabbits (Deyo 
et al., 1989) and act as a neuroprotective agent in aging hippocampal cells (Landfield, 1989). The efficacy of nimodipine in such in vivo studies is often attributed to vasodilatory effects on cerebral arterioles and to its lipophilic nature (compared to other DHPs), which may facilitate diffusion across the blood-brain barrier. However, when nimodipine is compared with DHPs of similar $K_{D}$ (in vascular smooth muscle) and lipophilicity, nimodipine retains a higher level of anticonvulsant efficacy (Meyer et al., 1988). Our results suggest that the efficacy of nimodipine in CNS indications may be based, at least in part, on the ability of nimodipine to block neuronal L-type calcium channels with high affinity in a time- and voltage-dependent manner.

Many hypotheses designed to explain the neuronal pathophysiology of brain aging (Khachaturian, 1989) and ischemia (Siesjö and Bengtsson, 1989) implicate the toxicity of sustained calcium influx to the underlying cellular processes (Rasmussen et al., 1990). High-affinity nimodipine block of detrimental calcium influx through L-type channels in pathologically compromised neurons combined with greater diffusion across the bloodbrain barrier may give nimodipine the advantage over other DHPs in treating CNS diseases. Such high-affinity block of neuronal L-type calcium channels throughout the PNS and CNS is likely to contribute to the overall neuroprotective action of this drug. The apparent insensitivity of well-polarized neurons to therapeutic concentrations of nimodipine may be best explained by the existence of DHP-insensitive calcium channels and their role in normal neural tunctioning combined with the voltage dependence of drug action such that block of L-type channels is minimal at hyperpolarized potentials. Nimodipinc-induced inhibition of sustained calcium influx through neuronal L-type calcium channels under conditions of prolonged depolarization during ischemia may allow compromised neurons to reestablish homeostasis. Thus, the therapeutic efficacy of nimodipine in treating pathologically affected neurons may well be determined by a combination of factors including the density of DHP binding sites, high-affinity block of calcium influx at depolarized potentials, and the lipophilic nature of this drug (Rhodes et al., 1985; McCarthy and Cohen, 1989).

\section{References}

Akaike N, Kostyuk PG, Osipchuk YV (1989) Dihydropyridine-sensitive low-threshold calcium channels in isolated rat hypothalamic neurones. J Physiol (Lond) 412:181-195.

Aosaki T, Kasai H (1989) Characterization of two kinds of highvoltage activated calcium channels in chick sensory neurons. Differential sensitivity to dihydropyridines and omega-conotoxin GVIA. Pfluegers Arch 414:150-156.

Bean BP (1984) Nitrendipine block of cardiac calcium channels: high affinity binding to the inactivated state. Proc Natl Acad Sci USA 81: $6388-6392$.

Bean BP (1989) Classes of calcium channels in vertebrate cells. Annu Rev Physiol 51:367-384.

Bean BP, Sturek M, Puga A, Hermsmeyer K (1986) Calcium channels in muscle cells isolated from rat mesenteric arteries: modulation by dihydropyridine drugs. Circ Res 59:229-235.

Boland LM, Dingledine R (1990) Multiple components of both transient and sustained barium currents in a dorsal root ganglion cell line. J Physiol (Lond) 420:223-245.

Boll W, Lux HD (1985) Action of organic antagonists on neuronal calcium currents. Neurosci Lett 56:335-339.

Carbone E, Lux HD (1984) A low voltage-activated, fully inactivating calcium channel in vertebrate sensory neurons. Nature 310:501-503.

Deyo RA, Straube KT, Disterhoft JF (1989) Nimodipine facilitates trace conditioning of the eye-blink response in aging rabbits. Science 243:809-8.11.
Docherty RJ, Brown DA (1986) Interaction of 1,4-dihydropyridines with somatic calcium currents in hippocampal CAl neurones of the guinea pig in vitro. Neurosci Lett 70:110-115.

Fox AP, Nowycky MC, Tsien RW (1987a) Kinetic and pharmacological properties distinguishing three types of calcium currents in chick sensory neurones. J Physiol (Lond) 394:149-172.

Fox AP, Nowycky MC, Tsien RW (1987b) Single-channel recordings of three types of calcium channels in chick sensory neurones. J Physiol (Lond) 394:173-200.

Hess P (1990) Calcium channels in vertebrate cells. Annu Rev Neurosci 13:337-356.

Hess P, Lansman J, Tsien R (1984) Different modes of calcium channel gating behaviour favored by dihydropyridine calcium agonists and antagonists. Nature 311:538-544.

Hirning L, Fox AP, McCleskey EW, Olivera BM, Thayer SA, Miller RJ, Tsien RW (1988) Dominant role of $\mathrm{N}$-type calcium channels in evoked release of norepinephrine from sympathetic neurons. Science 239:57-61.

Janis RA, Silver PJ, Triggle DJ (1987) Drug action and cellular calcium regulation. Adv Drug Res 16:309-591.

Jones SW, Jacobs LS (1990) Dihydropyridine actions on calcium currents of frog sympathetic neurons. J Neurosci 10:2261-2267.

Jones SW, Marks TN (1989) Calcium currents in bullfrog sympathetic neurons II. Inactivation. J Gen Physiol 94:169-182.

Kass RS (1987) Voltage-dependent modulation of cardiac calcium channel current by optical isomers of BAY K 8644: implications for channel gating. Circ Res 61:1-5.

Khachaturian $\mathrm{Z}$ (1989) The role of calcium regulation in brain aging: reexamination of a hypothesis. Aging 1:17-34.

Landfield P (1989) Calcium homeostasis in brain aging and Alzheimer's disease. In: Diagnosis and treatment of senile dementia (Bergener M, Reisberg B, eds), pp 276-287. Berlin: Springer.

Lipscombe D, Kongsamut S, Tsien R (1989) $\alpha$-Adrenergic inhibition of sympathetic neurotransmitter release mediated by modulation of N-type calcium-channel gating. Nature 340:639-642.

McCarthy RT (1989) Nimodipine block of L-type calcium channels in dorsal root ganglion cells. In: Nimodipine and central nervous system function: new vistas (Traber J, Gispen W, eds), pp 35-49. New York: Schattauer.

McCarthy RT, Cohen CJ (1986) The enantiomers of BAY K 8644 have different effects on calcium channel gating in rat anterior pituitary cells. Biophys J 49:432a.

McCarthy RT, Cohen CJ (1989) Nimodipine block of calcium channels in rat vascular smooth muscle cell lines: exceptionally highaffinity binding in A7r5 and A10 cells. J Gen Physiol 94:669-692.

McCleskey EW, Fox A, Feldman D, Cruz L, Olivera B, Tsien RW, Yoshikami D (1987) Omega-conotoxin: direct and persistent blockade of specific types of calcium channels in neurons but not muscle. Proc Natl Acad Sci USA 84:4327-4331

Meyer FB, Anderson RE, Sundt TM (1988) Anticonvulsant properties of dihydropyridine calcium antagonists. In: The calcium channel: structure, function and implications (Morad M, Nayler W, Kazda S, Schramm M, eds), pp 503-519. Berlin: Springer.

Middlemiss DN, Spedding M (1985) A functional correlate for the dihydropyridine binding site in rat brain. Nature 314:94.

Mogul DJ, Fox AP (1991) Evidence for multiple types of calcium channels in acutely isolated hippocampal CA3 neurones of the guineapig. J Physiol (Lond) 433:259-281

Nelson MT, Worley JF (1989) Dihydropyridine inhibition of single calcium channels and contraction in rabbit mesenteric artery depends on voltage. J Physiol (Lond) 412:65-91.

Nowycky MC, Fox AP, Tsien RW (1985a) Three types of neuronal calcium channels with different calcium agonist sensitivity. Nature 316:440-443.

Nowycky MC, Fox AP, Tsien RW (1985b) Long-opening mode of gating of neuronal calcium channels and its promotion by the dihydropyridine calcium agonist BAY K 8644. Proc Natl Acad Sci USA 82:2178-2182.

Perney TM, Hirning LD, Leeman SE, Miller RJ (1986) Multiple calcium channels mediate neurotransmitter release from peripheral neurons. Proc Natl Acad Sci USA 83:6656-6659.

Peroutka SJ, Allen GS (1983) Calcium channel antagonist binding sites labeled by ${ }^{3} \mathrm{H}$-nimodipine in human brain. J Neurosurg 59:933937.

Plummer MR, Logothetis DE, Hess P (1989) Elementary properties 
and pharmacological sensitivities of calcium channels in mammalian peripheral neurons. Neuron 2:1453-1463.

Rae JL, Levis RA (1984) Patch clamp recordings from the epithelium of the lens obtained using glasses selected for low noise and improved sealing properties. Biophys J 45:144-146.

Rampe D, Luchowski E, Rutledge A, Janis R, Triggle DJ (1987) Comparative aspects and temperature dependence of ${ }^{3} \mathrm{H}-1,4$-dihydropyridine calcium channel antagonist and activator binding to neuronal and muscle membranes. Can J Physiol Pharmacol 65:1452-1460.

Rane SG, Holz GG, Dunlap K (1987) Dihydropyridine inhibition of neuronal calcium current and substance $P$ release. Pfluegers Arch 409: 361-366.

Rasmussen H, Barrett P, Smallwood J, Bollag W, Isales C (1990) Calcium ion as intracellular messenger and cellular toxin. Environ Health Perspect 84:17-25.

Regan L (1991) Voltage-dependent calcium currents in Purkinje cells from rat cerebellar vermis. J Neurosci 11:2259-2269.

Regan L, Sah DWY, Bean BP (1991) Calcium channels in rat central and peripheral neurons: high-threshold current resistant to dihydropyridine blockers and omega-conotoxin. Neuron 6:269-280.

Rhodes DG, Sarmiento JG, Herbette L (1985) Kinetics of binding of membrane active drug to receptor sites. Diffusion-limited rates for a membrane bilayer approach of 1,4-dihydropyridine calcium channel antagonists to their active site. Mol Pharmacol 27:612-623.

Sanguinetti MC, Kass RS (1984) Voltage-dependent block of calcium channel current in the calf cardiac Purkinje fiber by dihydropyridine calcium channel antagonists. Circ Res 55:336-348.

Schroeder JE, Fischbach PS, Mamo M, McCleskey EW (1990a) Two components of high-threshold calcium current inactivate by different mechanisms. Neuron 5:445-452.

Schroeder JE, Fischbach PS, McCleskey EW (1990b) T-type calcium channels: heterogeneous expression in rat sensory neurons and selective modulation by phorbol esters. J Neurosci 10:947-951.

Scriabine A (1987) Neurochemical effects of nimodipine. New Trends Clin Neuropharmacol 1:85-93.

Scriabine A, Schuurman T, Traber J (1989) Pharmacological basis for the use of nimodipine in central nervous system disorders. FASEB J 3:1799-1806.

Scroggs RS, Fox AP (1991) Distribution of dihydropyridine and omega-conotoxin-sensitive calcium currents in acutely isolated rat and frog sensory neuron somata: diameter-dependent $L$ channel expression in frog. J Neurosci 11:1334-1346.

Siesjö BK, Bengtsson F (1989) Calcium fluxes, calcium antagonists, and calcium-related pathology in brain ischemia, hypoglycemia, and spreading depression: a unifying hypothesis. J Cereb Blood Flow Metab 9:127-140.

Swandulla D, Carbone E, Lux HD (1991) Do calcium channel classifications account for neuronal calcium channel diversity? Trends Neurosci 14:46-51.

TanPiengco PE, McCarthy RT (1990) High-threshold calcium currents in rabbit sensory neurons: differences in sensitivity to omegaconotoxin and nimodipine. Soc Neurosci Abstr 16:510.

Tsien RW, Lipscombe D, Madison DV, Bley KR, Fox AP (1988) Multiple types of neuronal calcium channels and their selective modulation. Trends Neurosci 11:431-438. 